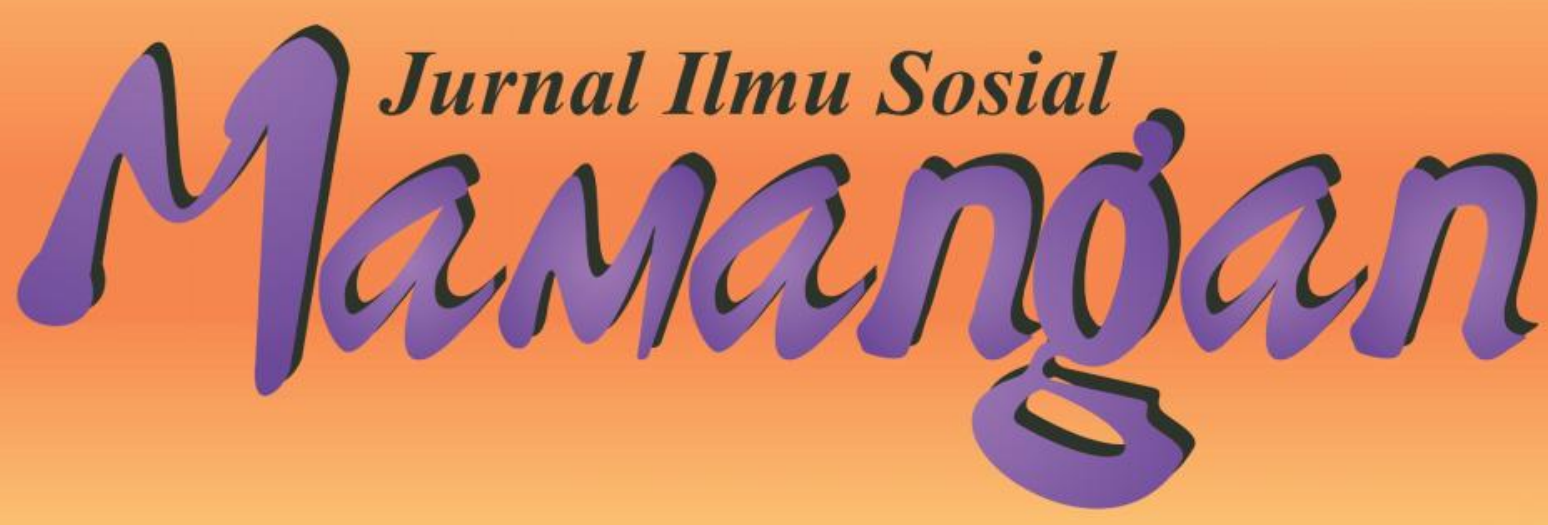

Kehidupan Sosial Ekonomi Petani Nilam Di Desa Taikako, Kec. Sikakap, Kab. Kepulauan Mentawai

YantiMurni, Ansofino \& Meldawati

Dampak Sosial Konflik Kinali 1999-2010

Welly Ibrahim, Ansofino \& Ahmad Nurul Huda

Pasang Surut Sosial Ekonomi Petani Cengkeh Di Nagari Koto Anau, Kec. Lembang Jaya, Kab. Solok 1960-2011

Yosefrizal, Sabar \& Witrianto

Perubahan Sosial Ekonomi Masyarakat Pasca Pengembangan Wisata Bahari Di Kepulauan Sikakap, Kabupaten Mentawai

Ismi Andriyani, Etmi Hardi \& Liza Husnita

Persepsi Masyarakat Petani Kelapa Terhadap Pendidikan Tinggi Anak Di Kecamatan Siberut Barat, Kabupaten Kepulauan Mentawai A. Tisnawati Tapondhadhai, Ansofino \& Ranti Nazmi

Kecendrungan Masyarakat Membeli Lahan Sengketa Di Kecamatan VII Koto, Kabupaten Tebo, Jambi

EsriEni Dewi Mukti, Slamet Rianto \& Dasrizal 


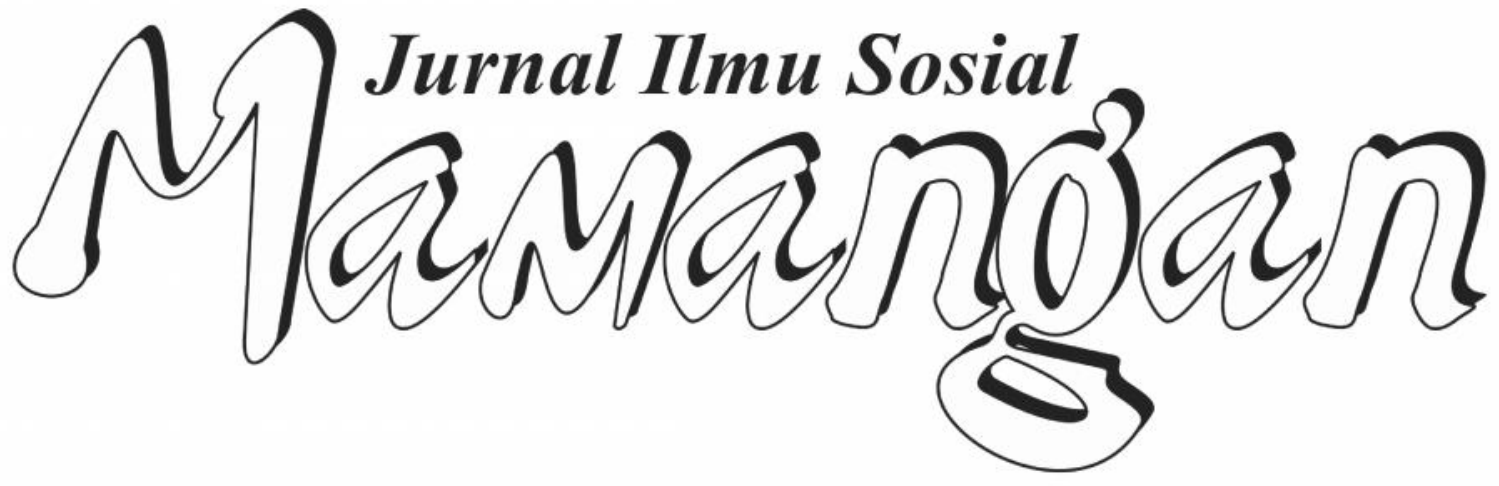




\section{Mitra Bestari}

Prof. Dr. Afrizal, MA. (FISIP, Unand Padang)

Dr. A. Latief Wiyata, M. Si. (Universitas Jember, Jember)

Prof. Dr. Badaruddin, M. Si. (FISIP, USU Medan)

Dr. Fikarwin Zuska, M. Si. (FISIP, USU Medan)

Nurus Shalihin, M. Si., Ph.D. (Fak. Ushuluddin IAIN Imam Bonjol Padang)

Dr. Semiarto A. Purwanto, M. Si. (FISIP, UI Jakarta)

Dr. Wahyu Wibowo, M. Si. (Universitas Nasional, Jakarta)

\section{Dewan Redaksi}

Dr. Zusmelia, M. Si.

Dr. Maihasni, M. Si.

Adiyalmon, S. Ag., M. Pd.

Firdaus, S. Sos., M. Si.

\section{Pemimpin Redaksi}

Firdaus, S. Sos., M. Si.

\section{Anggota Redaksi}

Dian Kurnia Anggreta, S. Sos., M. Si.

Rinel Fitlayeni, S. Sos., MA.

Surya Prahara, SH.

ISSN: 2301-8496

\section{Alamat Redaksi:}

Laboratorium Program Studi Pendidikan Sosiologi, STKIP PGRI Padang

Jl. Gunung Pangilun, Padang

Email: redaksimamangan@yahoo.com

Penerbit :

Program Studi Pendidikan Sosiologi, STKIP PGRI Padang

\section{Contac person :}

Firdaus (Hp. 085263881221/Email : daus gila@yahoo.com) 


\section{DAFTAR ISI}

Kehidupan Sosial Ekonomi Petani Nilam Di Desa Taikako, Kec. Sikakap, Kab. Kepulauan Mentawai

Yanti Murni, Ansofino \& Meldawati.

$60-72$

Dampak Sosial Konflik Kinali 1999-2010

Welly Ibrahim, Ansofino \& Ahmad Nurul Huda

Pasang Surut Sosial Ekonomi Petani Cengkeh Di Nagari Koto Anau, kec. Lembang Jaya, Kab. Solok 1960-2011

Yosefrizal, Sabar, Witrianto

Perubahan Sosial Ekonomi Masyarakat Pasca Pengembangan Wisata Bahari Di Kepulauan Sikakap, Kabupaten Mentawai

Persepsi Masyarakat Petani Kelapa Terhadap Pendidikan Tinggi Anak Di Kecamatan Siberut Barat, Kabupaten Kepulauan Mentawai

A. Tisnawati Tapondhadhai, Ansofino \& Ranti Nazmi.

Kecendrungan Masyarakat Membeli Lahan Sengketa Di Kecamatan VII Koto, Kabupaten Tebo, Jambi 


\title{
PERUBAHAN SOSIAL EKONOMI MASYARAKAT PASCA PENGEMBANGAN WISATA BAHARI DI KEPULAUAN SIKAKAP, KABUPATEN MENTAWAI
}

\author{
Ismi Andriyani ${ }^{1}$, Etmi Hardi ${ }^{2}$, Liza Husnita ${ }^{3}$ \\ ${ }^{1 \& 3}$ Sekolah Tinggi Keguruan dan Ilmu Pendidikan (STKIP) PGRI Sumatera Barat \\ 2 Universitas Negeri Padang
}

\begin{abstract}
The potential area to be a tourist destination is should attention to the elements of tourism development. Sikakap is one of the villages in the Mentawai islands which beautiful beach and sea. Since 2003, the development of marine tourism in the islands Sikakap has been run and driven by government. The marine tourism development in Sikakap village has impacted to coastal communities in Sikakap village. The development of marine tourism can boost the economy of coastal communities. Research conducted through qualitative and historical approach. The results is showed the marine tourism in the islands impacted to the socio-economic society in positive. The indicators is development of transportation facilities, hotels, markets and other public facilities and reduced unemployment.
\end{abstract}

Keywords : Development, Marine Tourism, Social Change, Socio-Economic.

\begin{abstract}
ABSTRAK
Daerah yang potensial menjadi daerah tujuan wisata dalam pengembangannya harus memperhatikan unsur-unsur pengembangan pariwisata. Sikakap merupakan salah satu desa di kepulauan Mentawai yang memilki pantai dan laut yang sangat indah. Sejak tahun 2003, pembangunan wisata bahari di kepulauan Sikakap telah dijalankan dan digerakkan oleh pemerintah. Pembangunan wisata bahari di desa Sikakap ini memberikan dampak positif bagi masyarakat pesisir pantai desa Sikakap. Pengembangan wisata bahari mampu menaikkan perekonomian masyakat pesisir pantai desa Sikakap. Artikel ini bertujuan untuk mendeskripsikan dampak pembanguan wisata bahari terhadap kondisi sosial ekonomi masyarakat. Penelitian dilakukan secara kualitatif dengan pendekatan historis. Hasil penelitian memperlihatkan bahwa wisata bahari yang dikembangkan di kepulauan Sikakap memberikan dampak positif terhadap perkembangan sosial-ekonomi masyarakat Sikakap. Hal ini ditunjukkan oleh perkembangan sarana transportasi, perhotelan, pasar dan fasilitas umum yang lainnya dan berkurangnya angka pengangguran.
\end{abstract}

Kata Kunci : pembangunan, wisata bahari, perubahan sosial, sosial ekonomi

PENDAHULUAN

Lautan adalah satu sumber daya pembangunan yang sempat ditinggalkan dan dilupakan dalam laju gerak pembangunan pada masa orde baru. Padahal, sebagai negara maritim, potensi 
daya kelautan, pesisir, dan pulau-pulau kecil sangatlah besar dan melimpah untuk dikelola secara optimal sehingga bisa memberi dampak multidimensi yang signifikan bagi negara dan bangsa. Indonesia merupakan negara kepulauan yang terdiri dari sektar 17.504 pulau dengan panjang garis pantai kurang lebih $81.000 \mathrm{~km}$. Di sepanjang garis pantai ini terdapat wilayah pesisir yang relatif sempit tetapi memiliki potensi sumber daya alam hayati dan non hayati, sumber daya buatan, serta jasa lingkungan yang sangat penting bagi kehidupan masyarakat.

Sebagai negara kepulauan, Indonesia memiliki potensi laut yang sangat besar. Namun selama ini potensi laut ini belum termanfaat dengan baik dalam meningkatkan kesejahteraan masyarakat pada umumnya, dan pemasukan devisa negara khususnya. Salah satu pembangunan yang potensial unuk dikembangkan dari daerah pesisir dan laut adalah wisata bahari, karena industri pariwisata adalah salah satu sumber penting penghasil devisa yang mendukung pertumbuhan ekonomi. Pada hakikatnya pantai dan laut adalah merupakan asset bagi pemerintah dan masyarakat pesisir pantai jika mereka memanfaatkan dan mengelolanya dengan baik dan benar. Salah satu asset yang dimaksud adalah dengan dibangun dan dikelolanya wisata bahari, karena masyarakat umumnya menyukai pantai. Hal ini disebabkan karena pantai mempunyai kesan indah tersendiri yang mana orang takkan pernah puas untuk melihat dan menikmati keindahannya.

Pada hakekatnya pengembangan wisata bahari merupakan respon dari perkembangan demand wisatawan pada skala dunia. Ha ini disebabkan karena adanya pertumbuhan populasi dunia, sehingga berpengaruh terhadap adanya peningkatan jumlah wisatawan internasional yang cukup besar. Salah satu kepulauan Indonesia yang terkenal keindahan pantainya adalah kepulauan Mentawai. Mentawai belakangan ini cukup menarik orang-orang dalam dan luar negeri. Terutama setelah Mentawai menjadi kabupaten terbungsu di propinsi Sumatera Barat. Banyak pelancong datang ke pulaupulau tepi barat tersebut. Secara alami, kepulauan Mentawai seakan-akan ditempatkan sebagai gugusan pulau penyangga dari hempasan gelombang laut samudera hindia dan samudera Indonesia terhadap pantai barat pulau sumatera. Secara geografis letaknya mengunungkan sekali.

Kepulauan ini juga diakui sangat strategis karena langsung berhadapan dengan kawasan Afrika Timur, Madagaskar dan negara-negara Asia Selatan seperti Yaman, Sriangka, India dan Miyanmar, begitu juga dengan kepulauan Andamar dan Nikobar. Mentawai adalah satu gugusan kepulau yang membujur dari utara ke selatan sepanjang pantai barat Sumatera Barat, dari Air Bangis hingga mendekati provinsi Bengkulu. Terdiri dari empat pulau besar, Siberut, Sipora, Pagai Utara, Pagai Selatan dan didampingi oleh hampir 7 pulau-pulau kecil lainnya. Mentawai terbagi menjadi empat kecamatan yaitu Siberut Utara, Siberut Selatan, Sipora dan Pagai Utara.

Peran wilayah pesisir dan laut sudah menjadi bagian penting dari kegiatan pembangunan perekonomian kabupaten kepulauan Mentawai, Sumatera Barat. Wilayah perairan kabupaten ini telah dipromosikan dan masuk ke dalam Indonesian marine toursim destination oleh menteri pariwisata. Hal ini didasari atas kenyataan bahwa perairn ini memliki kekayaan dan keanekaragaman hayati yang luar biasa (terumbu karang, ombak yang membentuk gula, pantai yang indah) yang menjadi daya tarik wisatawan mancanegara.

Perhatian pemerintah kabupaten kepulauan Mentawai telah terfokus pada pengembangan sektor wisata bahari, sesuai dngan sektor unggulan dari perencanaan pembangunan. Pada saat ini di beberapa lokasi dari kabupaten ini telah dikembangkan dan dimanfaatkan sebagai lokasi selancar, karena memiliki ombak yang cukup besar. Namun sarana dan prasarana dan sumber daya manusa masih terbatas, untuk menonjolkan dan menopang kegiatan wisata secara maksimal. Data yang tersedia dari kawasan tersebut belum memadai, sehingga pendayagunaan potensi pesisir kabupaten kepulauan Mentawai berikut sumberdaya secara optimal dan lestari, maka perlu dilakukan kajian tentang alternatif jenis wisata bahari selain selancar, 
seperti wisata pantai, wisata alam dan snorking, wisata pemancingan dan lainnya.

Meskipun daerah pantai memberikan peluang bisnis yang menjanjkan, tetapi pada kenyataannya jika dibandingkan dengan masyarakat yang tinggal di daerah di luar daerah pesisir lebih maju jika dibandikan dengan masyarakat yang tinggal di daerah pesisir. Dalam perkembangannya, masyarakat yang tinggal di daerah pesisir belum menunjukkan kemajuan yang berati dibandingkan dengan kelompok masyarakat lainnya. Keberadaan mereka sebagai bagian perubahan sosial ternyata tidak ditunjukkan secara positif dengan kehidupan ekonominya. Persoalan sosial paling dominan yang dihadapi daerah pesisir justru malah kemiskinan. Meski data akurat mengenai jumlah penduduk miskin di wilayah pesisir belum tersedia, data dari hasil-hasil penelitian yang ada menunjukkan adanya masalah kemiskinan di beberapa pesisir.

Sikakap merupakan salah satu desa di kepulauan Mentawai yang pantai dan lautnya sangat menjanjikan jika wisata baharinya dikelola dengan baik. Dari survey yang penulis lakukan pada masyarakat pesisir Sikakap umumya hidup dari nelayan dan bertani. Hidup mereka pas-pasan, dan bahkan kadang kekurangan. Oleh karena di daerah pemukiman masyarakat di Sikakap lebih banyak di daerah pesisir, maka jalur transportasi yang sering digunakan untuk melalui daerah-daerah Sikakap ini adalah transportasi laut. Desa Sikakap terletak di bagian paling timur Selat Sikakap yang meliputi kawasn yang termasuk pulau Pagai Utara dan Pagai Selatan. Desa Sikakap mempunyai luas $22.5 \mathrm{~km}^{2}$. Dua pulau tersebut dipisahkan oleh selat yang panjangnya hanya $7 \mathrm{~km}$ dan lebarnya tidak lebih dari $1 \mathrm{~km}$.

Kemiskinan, kesenjangan sosial antar kelompok masyarakat, keterbelakangan sosial, dan masalah-masalah sosial lainnya merupakan akibat yang berjalan seiring dengan kegiatan pembangunan bangsa. Kurang meratanya pembangunan di daerah mengakibat banyaknya daerah yang terisolir adalah kurangnya sarana dan prasarana transportasi. Umumnya sarana transportasi darat di desa Sikakap hanya jalan tanah yang hanya bisa dilalui oleh kendaraan roda dua, dan transportasi antar pulau yang dan speed boat yang jumlah armadanya sangat terbatas.

Pembangunan pada hakekatnya merupakan proses perubahan sosial ekonomi yang bertujuan meningkatkan taraf hidup, kualitas kehidupan dan manfaat manusia yang dilakukan secara sengaja dengan suatu rencana (Soekanto:1990). Sejak masa reformasi hingga saat ini, ada suatu perubahan haluan poliik pembangunan yaitu berdirinya departemen kelautan dan perikanan RI, dan hadirnya otonomi daerah sejak tahun 1999. Pengelolaan sumberdaya pesisir juga mendapat perhatian lebih besar sejalan dengan dibentuknya departemen kelautan dan perikanan (DKP). Sejalan dengan era otonomi, sejak tahun 2001 Pemerintah Daerah mempunyai kewenangan yang jelas dalam mengelola sumber daya pesisir dan pulau-pulau kecil secara bertanggung jawab sesuai pasal 10 UU No.22 tahun 1999 tentang Otonomi Daerah yang kemudian diganti dengan UU No. 32 tahun 2004 tentang Otonomi Daerah.

Daerah-daerah yang terisolir mulai dilakukan pembangunan fasilitas dan ataupun pembangunan atas potensi daerah tersebut. Seperti daerah Sikakap, salah satu bentuk pembangunan yang dilakukan adalah pembangunan wisata bahari. Pembangunan wisata bahari di desa Sikakap mulai dijalankan dan di gerakkan sejak tahun 2001, meskipun para wisatawan pada tahun-tahun sebelumnya sudah mengujungi kepulauan Mentawai untuk surfing. Salah satu obyek wisata yang terkenal yang telah dibangun di desa Sikakap yaitu resort dan fasilitas penginpan yang diperuntukkan bagi turis asing, dengan nama Macroni. Macroni terletak di Sialabu yang merupakan bagian pantai barat Sikakap. Desa Ssilabu merupakan desa terisolir di Sikakapp. Namun bersamaan dengan adanya kegiatan wisata bahari, bersamaan dengan hotel Macroni, hotel-hotel dan wisma serta fasilitas umum lainnya mulai bermunculan.

Pembangunan wisata bahari di Sikakap juga memberikan dampak positif bagi masyarakat pesisir pantai. Meskipun peluang ekonomi yang bisa digarap dari pembangunan wisata bahari ini belum tertangkap seluruhnya oleh masyarakat pesisir pantai desa Sikakap, tetapi hal ini sudah mampu menaikkan perekonomian 
dan sosial masyarakat pesisir pantai desa Sikakap meskipun belum maksimal. Ha ini di tunjukkan dengan berkurangnya angka pengangguran di daerah tersebut dan juga sebagian pemuda dan pemudi di daerah Sikakap tidak hanya mengandalkan pendapatannya dari hasil laut saja tetapi mereka sudah mampu mencari peluang dengan memanfaatkan para turis yang datang ke Sikakap. Ssalah satu bentuk peluang yang mereka tangkap adalah dengan menjadi pemandu bagi turis asing.

Artikel ini akan membahas tentang perkembangan dan perubahan masyarakat pesisir pantai desa Sikakap setelah pengembangan wisata bahari. Artikel terutama akan membahas perkembangan wisata bahari di kepulauan Sikakap dan perubahan sosial- ekonomi masyarakat desa Sikakap setelah adanya wisata bahari. Tulisan akan dibatasi pada perekembangan dan perubahan dalam rentang waktu 2003 sampai dengan tahun 2009. Pembatasan ini dilakukan karena pada tahun 2003 sampai dengan tahun 2009 terjadi perubaan yang signifikan secara sosial ekonomi masyarakat yang merupakan dampak perkembangan wisata bahari.

\section{GAMBARAN UMUM WISATA BAHARI DI KEPULAUAN SIKAKAP}

Kebijakan

pembangunan

kepariwisataan nasional dan daerah diarahkan menjadi andalan untuk mengggerakkan keadaan kegiatan ekonomi, sekaligus dapat berperan dalam menciptakan peluang lapangan dan peluang lapangan kerja. Pembangunan sektor kepariwisataan diharapkan akan dapat meningkatkan pendapatan asli daerah (PAD) dan memperbaiki kesejahteraan hidup masyarakat. Di Mentawai, pembangunan keparawisataan merupakan salah satu sektor andalan, terutama di kecamatan Sikakap. Berbagai program partisipatif dan bantuan pembangunan pariwisata telah dikembangkan di kabupaten Mentawai, khususnya di kepulauan Sikakap oleh lembaga internasional, pemerintah pusat, pemerintah daerah, lembaga pusat, lembaga ilmiah, lembaga swadaya masyarakat, swasta dan perseorangan guna menunjang pengembangan sektor kepariwisataan di daerah ini.
Kepulauan Sikakap telah ditetapkan oleh pemerintah pusat dan pemerintah daerah menjadi kawasan wisata bahari. Kondisi pesisir pantai, terumbu karang (coral reef) dan lautan dinilai memiliki potensi alam yang sangat potensial dan menarik untuk dikembangkan menjadi objek wisata bahari. Daya tarik pesisir, terumbu karang, dan kelautan inilah yang membuat pemerintah menjadikannya sebagai kawasan wisata bahari melalui SK Mentri kelautan No.91/Kpts-97/VI/97. Kepulauan Sikakap merupakan sebuah kabupaten di kepulauan Mentawai. Hingga saat ini, sebagian besar wilayah daratan kecamatan Sikakap masih berupa hutan. Kepulauan Sikakap memiliki pantai dan laut yang sangat indah, serta keberadaan taman nasional dan hutan hujan yang asri di kepulauan ini secara langsung mendukung berbagai kehidupan di pantai dan laut, termasuk sekor pariwisata.

Selama ini banyak turis yang datang untuk mrnikmati berbagai atraksi di wilayah pantai yang sangat terkesan akan keasrian hutan kepulauan Sikakap. Kepulauan Sikakap ini memiliki garis pantai sepanjang $412 \mathrm{~km}$. Potensi kepulauan Sikakap adalah ombaknya yan berulangulang dan sangat sesuai untuk dijadikan tempat selancar air (surfing). Menurut pengakuan dari para surfer yang pernah merasakan "cantiknya" ombak Mentawai yang teutama di kepulauan Sikakap, disebut-sebut sebagai tempat berselancar terbaik ketiga di dunia ini setelah kepulauan Hawai dan Tahiti. Kepulauan Mentawai tercatat memiliki 400 titik selancar yang sering dijadikan lokasi berselancar oleh para surfer. Dari 400 titik selancar, 23 titik diantaranya memiliki ombak berkala internasional. Daerah tersebut tersebar antara lain di daerah Nyang-Nyang, Karang Barat, Karoniki, Pananggelat dan Mainuk (Pulau siberut), Katiet Basua (Pulau Sipora) dan Sikakap (Pagai Utara).

Pada bulan-bulan musim gelombang, praktis kegiatan wisata bahari di kepulauan Sikakap tidak bisa berlangsung secara baik dan atau sangat terbatas. Pada musim gelombang sekitar bulan September sampai dengan bulan Januari setiap tahun umumnya kegiatan masyarakat nelayan di lautan praktis berhenti pula, seperti pelayaran, penangkapan ikan, mobilitas di 
kepulauan Sikakap. Kondisi arus dipengaruhi pula oleh kondisi musim atau angin, sehingga mempengaruhi kegiatan dan atau aktifitas mempengaruhi kegiatan dan atau kegiatan masyarakat nelayan dan wisatawan mancanegara maupun domestik. Dalam kondisi geografis demikian maka kegiatan wisata bahari praktis hanya bisa berlangsung 6 (enam) bulan dalam satu tahun. Kondisi ini memang berbeda dengan objek wisata bahari lainnya di Indonesia seperti Bali dan Manado (Bunaken) dimana kegiatan wisatanya bisa berlangsung sepanjang tahun. Pengaruh musim ini juga bisa berakibat pula terhadap semakin kecilnya dampak perkembangan pariwisata bahari terhadap kegiatan ekonomi masyarakat terumbu karang.

Kondisi terumbu karang yang beranekaragam disertai kehidupan biota lainnya serta pesisir pantai putih yang indah memang dimanfaatkan untuk kegiatan wisata bahari, seperti olah raga senam, snorkling, dan rekreasi pantai tetapi selama ini pantai di sini lebih banyak atau sering digunakan oleh wisatawan mancanegara, bahkan dapat dikatakan wisatawan domestik yang memanfaatkan kawasan ini untuk kegiatan wisata bahari relatif masih terbatas. Karena banyaknya turis yang datang dan menikmati wisata bahari di desa Silabu ini maka salah seorang investor asing asal Australia membangun resort di daerah Silabu ini dan diberi nama Macorani Resort. Penamaan Macorani Resort ini karena nama ombak yang ada di desa Silabu yang membentuk seperti macorani.

Macorani Resort merupakan satusatunya resort yang ada di kepulauan Sikakap dengan gaya dan konsep yang sangat menarik. Sebelum terjadi gempa tsunami pada tahun 2010 konsep dari bangunan Resort Macorani ini adalah resort yang dibangun di atas air, tetapi karena dampak gempa dan tsunami, konsep bangunanya pun diubah dan tidak lagi berada di atas air mengingat jika terjadi gempa dan tsunami lagi oleh karenanya bangunan Macorani Resort di bangun di pinggir pantai.

$\begin{array}{llr}\text { PERUBAHAN } & \text { SOSIAL MASYARAKAT } \\ \text { PASCA } & \text { PENGEMBANGAN } & \text { WISATA } \\ \text { BAHARI } & & \end{array}$

Peristiwa merupakan salah satu fenomena sosial, ekonomi, politik, budaya, dan teknologi, sehingga keadaan ini menjadi perhatian besar dari para ahli dan perencanaan pembangunan. Dalam perspektif geografi pariwisata terkait dengan fenomena mobilitas penduduk secara spesial yang terjadi karena perbedaan fungsi-fungsi ruang (dan isinya) bagi kehidupan komunitas masyarakat (Opperman:1980). Daya tarik wisata bahari di kawasan pesisir dan lautan Indonesia, merupakan anugrah yang dimiliki bangsa Indonesia yang tidak semua negara di dunia memilki kekayaan alam yang indah seperti ini, demikian juga dengan keragaman flora dan fauna dengan potensi yang demikian sempurna seperti apa yang ada di kepulauan Sikakap dimana pantainya yang begitu indah, laut dengan ombak yang tinggi, biota laut yang beragam dan keasrian lingkungan alamnya yang masih belum terjamah.

Kepulaun Sikakap terkenal dengan dengan keindahan pantai dan lautnya, merupakan objek wisata bahari yang baik untuk berselancar dan menyelam namun obyek wisata ini belum seutuhnya dimanfaatkan dan dikelola secara profesional sebagai objek wisata bagi wisatawan mancanegara maupun wisatawan domestik. Agar pembangunan wisata bahari terlaksana secara optimal, berkelanjutan dan handal, maka salah satu aspek yang sangat penting adalah aspek sosial, ekonomi dan budaya. Wisata bahari yang dikembangkan di kepulauan Sikakap memberikan dampak positif terhadap perkembangan sosial-ekonomi masyarakat di daerah kepulauan Sikakap. Dikatakan berdampak positif karna dengan adanya wisata bahari tersebut telah mampu merubah keadaan sosial-ekonomi dari masyarakat dari kepulauan Sikakap jika di bandingkan sebelum adanya perkembangan wisata bahari di kepulauan Sikakap ini.

Wisata bahari merupakan suatu bentuk wisata potensial termasuk di dalam kegiatan "clean industry". Pelaksanaan wisata bahari yang berhasil apabila memenuhi berbagai kompenen yakni terkait dengan kelestarian lingkungan alami, kesejahteraan penduduk yang mendiami wilayah tersebut. Agar supaya wisata bahari dapat berkelanjutan maka produk 
pariwisata bahari yang ditampilkan harus harmonis dengan lingkungan lokal spesifik. Dengan demikian masyarakat akan peduli terhadap sumber daya wisata karena memberikan manfaat sehingga masyarakat merasakan kegiatan wisata sebagai suatu kesatuan dalam kehidupanna. Cernea (1991) mengemukakan bahwa partisipasi lokal memberikan banyak peluang secara efektif dalam kegiatan pembangunan, dimana bahwa memberi wewenang atau atau kekuasaan pada masyarakat sebagai pemeran sosial dan bukan subjek pasif untuk mengelola sumberdaya membuat keputusan dan melakukan kontrol terhadap kegiatan-kegiatan yang mempengaruhi kehidupan sesuai dengan kemampuan mereka (Lindberg \& Hawkins : 1995).

\section{DAMPAK PERKEMBANGAN WISATA BAHARI TERHADAP EKONOMI MASYARAKAT}

Bisnis pariwisata sudah menjadi sektor andalan di banyak negara hal ini diperkuat oleh pernyataan Naisbit yang menyatakan bahwa pariwisata merupakan penghasil uang terbesar dan sektor terkuat dalam perekonomian global. Pengembangan pariwisata ini sudah tentu mempuyai kaitan dengan berbagai aspek kehidupan masyarakat baik dari segi ekonomi maupun dari segi sosial budaya. Apabila dilihat dari segi ekonomi bahwa pariwisata sebagai salah satu sumber pendapatan asli daerah (PAD) antara lain berupa pajak, retribusi daan sumber devisa bagi negara.

Dampak dari perkembangan wisata bahari yang terjadi di kepulauan Sikakap dilihat dari segi sarana dan prasarana banyak mengalami peningkatan. Hal ini ditunjukan dari sarana rasarana transportasi, perhotelan, pasar dan faslitas umum yang banyak mengalami perkembangan. Tidak hanya dari segi sarana transportasi saja yang mengalami perkembangan di kepulauan Sikakap sebagai dampak dari perkembangan wisata bahari tetapi dari tempat penginapan atau hotel, fasilitas umum seperti rumah sakit, pasar juga mengalami peningkatan ke arah yang lebih baik.

Di kepulauan Sikakap sekarang tersedia 9 buah penginaan dan satu resort sebagai tempat untuk para turis yang melakukan perjalanan wisata atau bagi pedagang yang datang untuk berjualan di kepulauan Sikakap ini. Pasar di kepulauan Sikakap juga mengalami perkembangan yang cukup pesat. Pasar di kepulauan Sikakap sebagai tempat transaksi untuk melakukan transaksi jual beli barang belanja harian atau barang kebutuhan lainnya terdapat di desa Sikakap. Dengan adanya wisata bahari ini masyarakat tidak hanya terpatok pada satu profesi saja semisal dalam hal ini nelayan, mereka terkadang menawarkan jasanya kepada para turis yang datang berkunjung ke kepulauan Sikakap, salah satu benuk jasa yang mereka tawarkan adalah menyewakan perahu yang mereka miliki atau menjadi pedagang dan bahkan juga menadi pengrajin. Otomatis dalam hal ini pendapatan masyarakat menjadi bertambah. Dapat disimpulkan bahwa dengan adanya wisata bahari ini masyarakat jadi pintar mencari peluang untuk menambah pendapatannya.

Wisata bahari sendiri mulai benarbenar dikelola dengan baik oleh pemerintah di kepulauan Sikakap pada tahun 2003, dimana pada tahun itu sedikit demi sedikit melancarkan perkembangan wisata bahari kepulauan Sikakap. Dampak dari perkembangan wisata bahari yang paling berarti bagi perubahan sosial ekonomi masyarakat Sikakap adalah bertambahnya pendapatan dari masyarakat, karna masyarakat tidak hanya mengandalkan suatu profesi sebagai sumber penghasilannya, tenaga ataupun keahlian yang mereka punya. Hasil studi COREMAP tahun 1997/1998 menunkkan rata-rata pendapatan rumah tangga nelayan Sikakap berkisar antara Rp 82.500 perbulan sampai Rp 225.000 per bulan, kalau dikonfersi pendapatan perkapita, angka tersebut ratarata setara dengan $\mathrm{Rp} 20.625$ sampai $\mathrm{Rp}$ 256.250 per kapita per bulan (Coremp: 1998). Berdasarkan dari hasil wawancara yang penulis lakukan dengan kepala camat dan dengan beberapa warga dengan profesi yang berbeda-beda diketahui bahwa pendapat rata-rata rumah tangga mereka perbulan adalah sebesar $\mathrm{Rp} 1.500 .000$ sampai dengan 5.000 .000 per bulan bagi berprofesi sebagai pedagang, 1.000 .000 sampai dengan Rp 3.000.000 perbulan bagi yang berprofesi sebagai nelayan $\mathrm{Rp} 750.000$ sampai dengan $\mathrm{Rp} 1.500 .000$ bagi yang 
mempunyai pekerjaan titak tetap sebagai ngojek.

\section{KESIMPULAN}

Kepulauan Sikakap telah ditetapkan oleh pemerintah pusat dan pemerintah daerah menjadi kawasan wisata bahari. Kondisi pesisir pantai, terumbu karang (coral reef) dan lautan dinilai memiliki potensi alam yang sangat potensial dan menarik untuk dikembangkan menjadi objek wisata bahari. Wisata bahari yang dikembangkan di kepulauan Sikakap memberikan dampak positif terhadap perkembangan sosial ekonomi masyarakat di daerah kepulauan Sikakap. Dikatakan berdampak positif sebab dikarenakan dengan adanya wisata bahari tersebut telah mampu merubah keadaan sosial ekonomi dari masyarakat di kepulauan Sikakap jika dibandingkan sebelum adanya perkembangan wisata bahari di kepulauan Sikakap.

Dampak dari perkembangan wisata bahari yang paling berarti bagi kondisi sosial ekonomi masyarakat adalah beragamnya sumber mata pencaharian. Hal ini dapat diligat dari masyarakat yang tidak hanya mengandalkan satu profesi sebagai sumber penghasilannya, tetapi juga mampu melakukan kegiatan ekonomi yang lain. Di musim turis banyak dating mereka memanfaatkan peluang yang ada guna menambah pendapatan mereka baik secara jasa, tenaga ataupun keahlian yang mereka punya yang berhubungan dengan kegiatan wisata.

\section{DAFTAR PUSTAKA}

Albert, 1998. Respon Masyarakat Terhadap Pelaksanaan Pembangunan Jalan Jambak-Padang Sarai. Skripsi-FISIP Universitas Andalas. Padang.

Ngadi, Bandiyono S \& Sudiyono, 2007. Kondisi Sosial Ekonomi Masyarakat Desa Sikakap, Kabupaten Kepulauan Mentawai. LIPI PRES. Jakarta.

Daliyono, Imron M \& Wahyono A, 2007. Kondisi Sosial Ekonomi Masyarakat Desa Katurai, Kabupaten Kepulauan Mentawai. LIPI PRESS. Jakarta.

Desirre, Zuraida, 1993. Masyarakat Dan Manusia Dalam Pembangunan. Granmedia Pustaka Utama. Jakarta.

Sughandy, Aca, 1990. Perubahan Sosial Dan Pembangunan Di Indonesia. LP3ES. Jakarta.

Suwantoro, Gamal, 2001. Dasar-Dasar Pariwisata. ANDI. Yogyakarta. 
